\title{
Effects of IFRS on Accounting Information Quality: Evidence for Brazil
}

\author{
Julio Cesar Araujo da Silva Junior ${ }^{1}$, João F. Caldeira ${ }^{2} \&$ Hudson da Silva Torrent ${ }^{3}$ \\ ${ }^{1}$ Department of Applied Social Sciences, Community University of the Region of Chapecó, Chapecó, Brazil \\ ${ }^{2}$ Department of Economics, Federal University of Rio Grande do Sul, and CNPq, Porto Alegre, Brazil \\ ${ }^{3}$ Department of Statistics, Federal University of Rio Grande do Sul, Porto Alegre, Brazil \\ Correspondence: Julio Cesar Araujo da Silva Junior, Department of Applied Social Sciences, Community \\ University of the Region of Chapecó, Chapecó (SC), Brazil. Tel: 55-49-3321-8283. E-mail: \\ julio.econometria@gmail.com
}

Received: March 19, 2017

Accepted: April 6, 2017

Online Published: April 15, 2017

doi:10.5539/ijef.v9n5p44

URL: https://doi.org/10.5539/ijef.v9n5p44

\begin{abstract}
Understanding the effects of the International Financial Reporting Standards (IFRS) on accounting quality is fundamental for policy makers and financial market players in general. This paper analyzes whether the adoption of IFRS in Brazil has had the impact on accounting informational quality. To this end, a differentiated empirical strategy was adopted based on two steps: first, a matching of voluntary adopters of norms and non-adopters by propensity score is performed to construct control groups. This is important to mitigate the selection bias problem. Second, the measures of value relevance, timeliness and conservatism of accounting information are estimated using panel data models. The period of analysis extends from 2006 to 2010, with annual information for the first stage and quarterly for the second. The results show a positive impact of international standards on the value relevance. However, for the measures of timeliness and conservatism, sufficient evidence was not found to indicate any impact on the group of companies evaluated.
\end{abstract}

Keywords: accounting information quality, Brazil, IFRS, panel data analysis, propensity score matching

\section{Introduction}

The process of convergence to International Financial Reporting Standards (IFRS) has been occurring in several countries since the 2000s. Currently, more than 130 countries require or permit the use of international standards. The decision to adopt IFRS is mainly motivated by two factors: the comparability of information among countries and the quality of accounting information. Both can contribute to the reduction of uncertainty and information asymmetry among economic agents and result in lower transaction costs and increased investments among regions (Tendeloo \& Vanstraelen, 2005; Iatridis, 2010; Olfa \& Hamadi, 2015).

Most studies that investigate the impacts of adopting IFRS on accounting information point to benefits derived from the standard. However, some studies do not identify information improvement as an exclusive effect of adopting IFRS, arguing that the result may have origins in other sources related to country characteristics (Soderstrom \& Sun, 2007) and other economic factors (Hail, Leuz, \& Wysocki, 2010). In addition, there are influences related to the different cultures and languages of each country, as opposed to the adoption of standards (Dowa, Elgammi, Elhatab, \& Mutat, 2017).

In Brazil, the convergence process began with the period of voluntary adoption of international standards by companies in 2008 and consolidated in 2010 with full adoption. A large number of national surveys point to a positive impact of IFRS in improving accounting information, although they are not unanimous in assessing the different dimensions of accounting quality (Santos \& Cavalcante, 2014).

A common aspect to most of the studies specific to Brazil is the methodological procedure adopted. Generally, it involves the inclusion of dummy variables to identify the years of adoption of the norms and performs comparisons of the results of information quality variables in periods before and after the adoption of IFRS for the same group of companies. This procedure, used to isolate the effect of standards, is not considered the first best in policy impact assessment literature and presupposes strong hypotheses regarding other observed and unobserved factors that may interfere with the results of interest. An example of a problem that this procedure 
may have is selection bias because the error term of the estimation equation of accounting quality may contain information that is also correlated with the indicator dummy treatment, as illustrated generally in Khandker, Koolwal and Samad (2010).

In the problem at hand, data do not come from randomized trials. Each company is responsible for choosing whether or not it adopts international standards. In seminal work, Rosenbaum and Rubin (1983) proposed propensity score matching as a method to reduce the bias in the estimation of treatment effects with observational data sets. These methods have become increasingly popular in the evaluation of economic policy interventions. Since in observational studies assignment of subjects to the treatment and control groups is not random, the estimation of the effect of treatment may be biased by the existence of confounding factors. Propensity score matching is a way to "correct" the estimation of treatment effects controlling for the existence of these confounding factors based on the idea that the bias is reduced when the comparison of outcomes is performed using treated and control subjects who are as similar as possible.

Specifically, it is proposed to use quality measures based on market attributes, listed in Francis, Lafond, Olsson and Schipper (2004), and to calculate the effect of IFRS through the results of the treatment and control groups. For this purpose, a two-step strategy is adopted; in the first step, the propensity score matching method is used to construct a control group statistically comparable to the treatment group, with annual data. In the second, we estimate information quality measures with panel data models and quarterly company information.

Thus, given the different characteristics that may influence accounting information quality, the non-convergence of the results in the literature and the procedures used so far to measure the effect of IFRS in Brazil, it becomes relevant to carry out an evaluation from another methodological approach. In this context, the article aims to assess whether the adoption of international accounting standards is associated with a higher accounting information quality in Brazil. The main contribution of this paper is the proposition of an adequate substitute to the counterfactual of the adopters of the norms and in the use of evaluation procedures previously not performed for Brazil. The results suggest a good balance between the treatment and control groups, indicating the construction of a group that approximates the condition of the firms before the adoption of the norms.

This paper is structured in five more sections in addition to the introduction. In the second section, a review is carried out on the impacts of IFRS and dimensions of accounting information quality. In the third section, the matching methods and the equations of interest are presented and discussed. The fourth section outlines the empirical strategy used to evaluate standards. Then, the results and the analysis performed are presented. The concluding section contains, in addition to the final considerations, the limitations of the study.

\section{Adoption of IFRS and Accounting Information}

In the accounting and finance literature, some papers are dedicated to reviewing and systematizing the results found on the impact of IFRS, such as Ahmed, Chalmers and Khlif (2013). In this work, a meta-analysis of studies on the adoption of the international norms is made, with results indicating the increase in the accuracy of analysts' forecasts and the non-reduction of discretionary accumulations after its adoption. However, these results are sensitive to the characteristics of countries and companies, as Soderstrom and Sun (2007) note. The authors mention that, in addition to the quality of standards, the accounting information disclosed by companies is influenced by the legal and political system to which they are subject, which differs among countries. Hail et al. (2010) also advise on the possibility that valuations may be deceptively the result of economic factors other than international accounting standards.

Some papers try to control the characteristics of different countries and carry out evaluations with samples containing firms of more than one nationality. Houqe, Van Zijl, Dunstan, and Karim (2012), using data from firms from 46 countries in the period from 1998 to 2007, concluded that the accounting information quality increases with the adoption of IFRS in locations where the investor protection regime is stronger. However, Barth, Landsman, and Lang (2008), with a sample of 21 countries in the period from 1994 to 2003, indicate that the companies that adopted IFRS were less likely to be involved in smoothing the results and more likely to recognize losses. Similar results can be found in the works of Armstrong, Barth and Riedl (2010).

Other country-level studies indicate some significant impacts on accounting quality due to the adoption of IFRS such as Karampinis and Hevas (2009) for Greece, Kargin (2013) and Bilgic and Ibis (2013) for Turkey and Apergis (2015) for countries in the Middle East and North Africa. For France, Garrouch (2016) finds an increase in investments due to the adoption of the standards. In the United Kingdom, Iatridis (2010) notes that the adoption of IFRS reduces the possibility of management results and increases the relevance of the information. However, there are studies that do not find association or indicate the opposite direction, such as Callao, Jarne, and Laínez (2007), for Spain, and Klimczak (2011), for Poland. 
Another important aspect in the comparison of the results found in the literature is the lack of an exact definition of accounting information quality. Several papers use different dimensions to evaluate this characteristic; see the example of Barth et al. (2008), where the quality of the information is verified using four different dimensions. In addition, the model specifications themselves and the variables used have undergone changes in their calculation form over time. For the most part, they were elaborated in the search for solutions to existing problems, such as the scale effect described in Easton and Sommers (2003).

A frequently used classification of these measures of quality accounting information is based on market attributes, listed in Francis et al. (2004) as value relevance, timeliness and conservatism. The value relevance can be considered as the extent to which accounting information synthesizes and captures information that affects company value, as described in Francis and Schipper (1999). In summary, it can be defined as the association between the accounting information and the market value of the company (Barth, Beaver, \& Landsman, 2001). Timeliness refers to the information embodied in stock returns, which indicates that the higher the quality, the more significant it is to describe the accounting profit. Conservatism refers to an asymmetric recognition of good and bad news in accounting profits, with the proposition that accounting results reflect negative returns faster than positive returns.

Specifically, in relation to the studies about Brazil, which use the dimensions based on market attributes, Lima (2010) stands out as the pioneer. The author makes an analysis of the value relevance in the period of voluntary adoption of the international standard in the country. His results attest to the increase of this measure from the voluntary adoption of the norms. In this respect, Gonçalves, Batista, Macedo, and Marques (2014) conclude that the accounting information became more relevant in IFRS standars.

Santos and Cavalcante (2014) evaluated the effect of the adoption of IFRS in Brazil according to three measures based on market attributes. Their results indicate that the adoption of IFRS increased the associative capacity of accounting profit, reduced non-significant informational timeliness and had no effect on conditional conservatism. Santos, Lima, Freitas, and Lima (2011) present similar results for accounting conservatism and did not find evidence of the impact of the adoption of IFRS on this measure for Brazilian publicly traded companies.

A common feature of the studies applied in Brazil is the methodological procedure adopted to evaluate the effects of the international standard. In general, it does not involve the construction of a counterfactual appropriate for measuring the impact of IFRS. Therefore, starting from a different methodological strategy than those adopted until now, and based on the assumption that international norms are of better quality than Brazil's domestic standards, the following research hypotheses are formulated:

H1 - Accounting information has greater association with the contemporaneous returns in the IFRS accounting standard than in the domestic standards;

H2 - The adoption of IFRS in Brazil increased the informational timeliness of accounting profit, and

H3 - The adoption of IFRS in Brazil increased the level of conservatism in accounting profit.

\section{Matching and Accounting Information Quality Models}

The matching method is used with the intention of constructing a control group similar to the treatment group in terms of observable characteristics. One of its advantages, which is useful for assessing standards, is that it offers a way of estimating the average effect of treatment in situations where controlled randomization is impossible and when there is no natural experiment that can provide a substitute (Khandker et al., 2010). Another good point is that it provides a way to select the observations on which other methods can be applied next, which, according to Ho, Imai, King, and Stuart (2011), increases efficiency.

\subsection{Propensity Score}

The use of all existing characteristics affecting treatment in the matching procedure may be infeasible in view of the unavailability of data. Moreover, as the number of characteristics increases, finding for each treated firm a similar counterpart in the control group becomes more difficult. A solution to these problems was proposed in the work of Rosenbaum and Rubin (1983), the propensity score. It is a summary function of observed variables that can affect treatment, avoiding the need for an exact match for all variables. In a formal way, the propensity score is defined as:

$$
e(x)=\operatorname{Pr}\left(T_{i}=1 \mid X_{i}=x\right)
$$

where $T$ takes the value of 1 , indicating the participation of treatment for $i$, and 0 otherwise; $X$ is the vector of observable characteristics pretreatment.

The assumptions needed to identify the effect of treatment are conditional independence and the presence of a 
common support. Mathematically, the hypothesis can be written as follows:

$$
T_{i} \perp\left(y_{i 0}, y_{i 1}\right) \mid X_{i}
$$

and

$$
0<e(x)<1
$$

where $y$ is the result of the interest variable, which assumes value $y_{1}$ if it has received treatment $(T=1)$ and $y_{0}$ if it has not received treatment $(T=0)$, and $i$ indicates the unit.

These hypotheses postulate that when comparing companies of the treatment group with companies of the control group, the only factor that discerns the observed results of these companies would be to adopt or not to adopt the IFRS. A more detailed explanation can be found in Khandker et al. (2010).

The most commonly used method to estimate the propensity score is through probit or logit models. Following the notation of Imbens (2015), the estimator of the propensity score, $\hat{e}(x)$, can be specified as:

$$
e(x)=\frac{\exp (h(x) \gamma)}{1+\exp \left(h(x)^{\prime} \gamma\right)^{\prime}}
$$

where $h(x)$ is a linear function of the covariates $\mathrm{X}$ and $\gamma$ is an unknown parameter estimated by maximum likelihood:

$$
\begin{gathered}
\hat{\gamma}_{m v}(T, X)=\arg _{\gamma} \max L(\gamma \mid T, X) \\
=\arg _{\gamma} \max \sum_{i=1}^{N}\left\{T_{i} \cdot h\left(X_{i}\right)^{\prime} \gamma-\ln \left(1+\exp \left(h\left(X_{i}\right)^{\prime} \gamma\right)\right)\right\}
\end{gathered}
$$

The propensity score estimator is then:

$$
\hat{e}(x \mid T, X)=\frac{\exp \left(h(x) \widehat{r}_{m v}(T, X)\right)}{\left.1+\exp (h(x))_{m}(T, X)\right)}
$$

The matching will also depend on a metric that will define the proximity of the propensity score of the treated units to the propensity score of the untreated units. For this application, the use of two different algorithms, nearest neighbor and genetic matching, is proposed. The first minimizes the absolute difference in the propensity score between units $i$, the treatment group, and the control group $j$. The second one uses a search algorithm to find a set of weights for each covariant such that an optimal equilibrium is reached.

\subsection{Models of Accounting Information Quality}

In this study, we consider measures of accounting quality based on market attributes, listed in Francis et al. (2004) as value relevance, timeliness and conservatism. This choice is based on its simplicity of construction, easy data access, extensive use in the literature and involvement of both accounting and market variables.

\subsubsection{Value Relevance}

The equations used to capture the relevance of accounting profits are based on the work of Ohlson (1995), with some adaptations. As a control variable, the net equity per share was weighted and the explanatory variables weighted by the closing price of period $t-1$, a procedure similar to that adopted in the empirical investigations of Barth and Clinch (2009) and Barth et al. (2008). These procedures aim at the elimination of the scale effect, which can cause, for example, biased coefficients and problems of heteroscedasticity, as explained in Gil-Alana, Iniguez-Sanchez and Lopez-Espinosa (2011). Thus, the following equations are proposed:

$$
\begin{gathered}
\frac{P_{i t}}{P_{i t-1}}=\beta_{0}+\beta_{1} \frac{B V E_{i t}}{P_{i t-1}}+\beta_{2} \frac{E A R N_{i t}}{P_{i t-1}}+\varepsilon_{i t} \\
\frac{P_{i t}}{P_{i t-1}}=\beta_{0}+\beta_{1} \frac{B V E_{i t}}{P_{i t-1}}+\beta_{2} \frac{E A R N_{i t}}{P_{i t-1}}+\delta_{1} I F R S_{i t}+\varepsilon_{i t} \\
\frac{P_{i t}}{P_{i t-1}}=\beta_{0}+\beta_{1} \frac{B V E_{i t}}{P_{i t-1}}+\beta_{2} \frac{E A R N_{i t}}{P_{i t-1}}+\delta_{1} I F R S_{i t}+\delta_{2} I F R S_{i t} \times \frac{E A R N_{i t}}{P_{i t-1}}+\varepsilon_{i t}
\end{gathered}
$$

where $\mathrm{P}_{\mathrm{it}}$ is the stock price of firm $i$ at time $t, \mathrm{BVE}_{\mathrm{it}}$ is the book value of equity per share of firm $i$ at time $t$, EARN $_{\text {it }}$ is the net earnings per share for firm $i$ at time $t$; all these weighted by the share closing price in $t-1$ for firm $i$. The variable IFRS $i$ has a value of 1 for the quarters in which the firm $i$ voluntarily adopted the norms and 0 otherwise; and $\varepsilon_{i t}$ is the error term.

The evidence of an association between accounting profit and market variables implies results of parameters $\beta_{2}>$ 0 . If the adoption of IFRS increased this relation, a coefficient $\delta_{2}>0$ is expected. Finally, if the adoption of IFRS on average increases the market value of the companies, the $\delta_{1}$ will be positive.

\subsubsection{Timeliness and Conservatism}

The measures of timeliness and conservatism used are based on the works of Beaver, Lambert, and Morse (1980) 
and Basu (1997). Thus, equations 10 to 12 are proposed to verify the timeliness:

$$
\begin{gathered}
\frac{E A R N_{i t}}{P_{i t-1}}=\alpha_{0}+\alpha_{1} R_{i t}+\varepsilon_{i t} \\
\frac{E A R N_{i t}}{P_{i t-1}}=\alpha_{0}+\alpha_{1} R_{i t}+\dot{\delta}_{1} I F R S_{i t}+\varepsilon_{i t} \\
\frac{E A R N_{i t}}{P_{i t-1}}=\alpha_{0}+\alpha_{1} R_{i t}+\dot{\delta}_{1} I F R S_{i t}+\dot{\delta}_{2} I F R S_{i t} \times R_{i t}+\varepsilon_{i t}
\end{gathered}
$$

where $R_{i t}$ is the log-return, calculated by the natural logarithm of the ratio of prices of periods $t$ and $t-1$.

In these equations, the coefficient $\alpha_{1}$ captures the timeliness of the accounting profit, which, according to the theory, should have a positive sign. The assumption that the adoption of IFRS on average increases companies' earnings can be tested by the result of parameter $\dot{\delta}_{1}$. The parameter $\dot{\delta}_{2}$ relates the change in informational timeliness arising from the adoption of the standards; if they have become the timeliest accounting profit, these coefficients are positive.

For the analysis of conservatism, the following equations are proposed:

$$
\begin{gathered}
\frac{E A R N_{i t}}{P_{i t-1}}=\alpha_{0}+\alpha_{1} R_{i t}+\alpha_{2} N E G_{i t}+\alpha_{3} N E G_{i t} \times R_{i t}+\varepsilon_{i t} \\
\frac{E A R N_{i t}}{P_{i t-1}}=\alpha_{0}+\alpha_{1} R_{i t}+\alpha_{2} N E G_{i t}+\alpha_{3} N E G_{i t} \times R_{i t}+\dot{\delta}_{1} I F R S_{i t}+\varepsilon_{i t} \\
\frac{E A R N_{i t}}{P_{i t-1}}=\alpha_{0}+\alpha_{1} R_{i t}+\alpha_{2} N E G_{i t}+\alpha_{3} N E G_{i t} \times R_{i t}+\dot{\delta}_{1} I F R S_{i t}+\ddot{\delta}_{2} N E G_{i t} \times R_{i t} \times I F R S_{i t}+\varepsilon_{i t}
\end{gathered}
$$

where $\mathrm{NEG}_{i t}$ is a dummy variable that takes 1 when $R_{i t}$ is negative and 0 otherwise.

In these equations, the coefficients $\alpha_{2}$ and $\alpha_{3}$ capture the conditional conservatism of the accounting profit. In the case of asymmetric recognition of economic loss with respect to gain, these coefficients will show $\alpha_{2}<0$ and $\alpha_{3}>0$. The parameter $\ddot{\delta}_{2}$ captures the change in conservatism from the change in the norm and that the positive value indicates that companies adopting IFRS have more conservative profits.

\section{Empirical Strategy and Data}

The process of evaluating the impact of international standards on measures of accounting information quality involves two steps: the matching and the estimation of accounting quality measures. The first step comprises the separation of firms into voluntary adopters and non-adopters of standards; estimation of propensity scores; verification of the closest scores for the choice of pairs, and selection of the control group. The second step uses the data from the treatment and control groups to estimate the measures of accounting quality through panel data models.

The identification of companies' voluntary adoption took into account the information disclosed on the CVM website and the Economática ${ }^{\circledR}$ database, resulting in 25 companies with sufficient data for the proposed estimates. For matching, we used logit models and annual data of voluntary and non-voluntary adoptive firms in periods prior to their adoption.

The selection of pairs of companies takes into account the proximity of the values of these probabilities, based on the results of two different algorithms, the nearest neighbor matching and genetic matching. The decision of which one to use was taken in function of the best results of the average differences of the variables between the presented groups. Detailed information about the algorithms can be obtained from Abadie and Imbens (2006), Ho et al. $(2007 ; 2011)$.

In operation, to avoid duplication of potential match companies over time, all pairs found in one year were withdrawn from the base in the following years. The only imposition established for the use of the data was that the pairs of companies presented the same time horizon of information among themselves.

For the estimates of the second stage, Equations 7 to 15, data from the treatment and control group companies were used quarterly, totaling 730 firm-quarter information, structured in an unbalanced panel. The models were panel data with fixed effects, random effects and pooled OLS (chosen according to the panel diagnostic tests), which may have been consulted for its properties and verification tests in Cameron and Trivedi (2005). Moreover, in Equations 9 and 15, an indicative dummy for year variables was included, assuming 1 for the analyzed year and 0 for others.

\subsection{Data and Sample}

The information was collected from all Brazilian publicly traded firms, except for firms registered in the financial category because they have specific legislation. The characteristics and forms of calculation of the variables, the sources of collection and the stages of use are listed in Table 1. 
In the matching stage, we used annual data from 2006 to 2009, and the variables were: size, book value of equity (BV), financial leverage ratio (LEV), market of book (MOB), market value (MV) and issuance of American depositary receipt (ADR). Based on the results of Paul, Walton and Yang (2012), these variables were chosen as the main determinants of the voluntary adoption of international standards by companies.

Table 1. Description of the data

\begin{tabular}{|c|c|c|c|}
\hline & Variable & Step & Frequency/Source \\
\hline EARN & ratio of net income - dividends and average outstanding shares & Evaluation of the Standard & Quarterly /Economática \\
\hline SIZE & natural logarithm of a firm's total assets & Matching & Yearly /Economática \\
\hline $\mathrm{R}$ & $\log$-return & Evaluation of the Standard & Quarterly /Economática* \\
\hline $\mathrm{P}$ & closing price & Evaluation of the Standard & Quarterly /Economática* \\
\hline BVE & book value of equity per share & Evaluation of the Standard & Quarterly /Economática \\
\hline BV & book value of equity & Matching & Yearly /Economática \\
\hline IFRS & $\begin{array}{l}\text { a dummy variable with a value of } 1 \text { for the quarters in which } \\
\text { firm i voluntarily adopted the norms and a value of } 0 \text { otherwise }\end{array}$ & Evaluation of the Standard & Quarterly /Economática e CVM \\
\hline LEV & ratio of total debt and total assets & Matching & Yearly /Economática \\
\hline MOB & ratio of market value and book value of equity & Matching & Yearly /Economática \\
\hline MV & closing price $\mathrm{x}$ number of shares & Matching & Yearly /Economática \\
\hline $\mathrm{ADR}$ & $\begin{array}{l}\text { a dummy variable with a value of } 1 \text { for the firm that emits } \\
\text { American Depositary Receipt and a value of } 0 \text { otherwise }\end{array}$ & Matching & Yearly /NYSE \\
\hline
\end{tabular}

Note. The collection sources were Economática ${ }^{\circledR}$ database and virtual websites of the Brazilian Securities Commission (CVM) and The New York Stock Exchange (NYSE).

* When available, preferred shares were used because of their greater liquidity, and their prices were adjusted by the proceeds, according to criteria used by the Economática ${ }^{\circledR}$ base.

In respect to the estimation phase of accounting information quality measures, the data are of quarterly frequency and extend from 1/2006 to 3/2010. The variables used in this step were mentioned in section 3 .

\section{Results}

The matching process resulted in 25 pairs of companies, one pair for each voluntary adopter, built on data from the years 2006, 2007 and 2009. The attempt to match more than one company to a voluntary adopter resulted in a worsening in the results of mean differences of variables between groups. The same case occurred with the results of the matching of 2008, and for that reason the pairs of 2007 were kept in their place.

To verify the validity of the matching results by propensity score, the fulfillment of the hypotheses of the method was verified. In this case, evidence of common support was sought, observing the intervals of scores between the groups and the decrease of the mean differences of the values of the variables between groups. The minimum scores for the group of voluntary adopters and the maximum scores for the group of paired non-adopters respect the imposition of the second hypothesis of the model, presenting ranges of propensity scores of $[0.0372 ; 0.8051]$ in 2006, [0.0322; 0.7090] in 2007 and [0.0289; 0.5774] in 2009, according to the results in Table 2. In addition, the likelihood ratio tests were performed on the logit models that gave rise to the results, which presented significant results at $1 \%$ (see Cameron \& Trivedi, 2005 for more details about the test).

Table 2. Scores, groups, and firms per year

\begin{tabular}{ccccccc}
\hline Year & \multicolumn{2}{c}{2006} & \multicolumn{2}{c}{2007} & \multicolumn{2}{c}{2009} \\
\hline Algorithm & \multicolumn{2}{c}{ Nearest Neighbor Matching } & \multicolumn{2}{c}{ Genetic Matching } & \multicolumn{2}{c}{ Nearest Neighbor Matching } \\
\cline { 2 - 7 } Firms & Control & Treatment & Control & Treatment & Control & Treatment \\
All & 226 & 20 & 281 & 22 & 269 & 19 \\
Matched & 20 & 20 & 22 & 22 & 19 & 19 \\
Unmatched & 206 & 0 & 259 & 0 & 250 & 0 \\
Minimum score of the pairs & 0.0368 & 0.0372 & 0.0261 & 0.0322 & 0.0286 & 0.0289 \\
Maximum score of the pairs & 0.8051 & 0.8641 & 0.709 & 0.7048 & 0.5774 & 0.6676 \\
\hline
\end{tabular}

Note. The software used for this phase was the R Core Team (2016), through the functions of the library matchit, found in the work of Ho et al. (2011).

The results of the matching show lower mean differences between the group of voluntary adopters and control than when compared to all firms, for all variables used, except for the market of book of 2006, according to data 
from Table 3. In the graphic check, a good matching adjustment is confirmed. The areas of densities of the control groups constructed in the years 2006, 2007 and 2009, overlapping those of the density of the voluntary adopters, are observed almost completely as can be observed in Figure 1A. The other graphical results of the matching, histogram and scatter plot of the scores, of groups of voluntary adopters, controls and the whole sample are shown in figures $2 \mathrm{~A}$ to $7 \mathrm{~A}$ in Appendix A.

Table 3. Results of the matching - 2006, 2007 and 2009

\begin{tabular}{|c|c|c|c|c|c|c|}
\hline & \multicolumn{3}{|c|}{ Mean values before matching } & \multicolumn{3}{|c|}{ Mean values after matching } \\
\hline \multicolumn{7}{|c|}{2006} \\
\hline Variable & Treated & Raw Control & Mean difference & Treated & Matched Control & Mean difference \\
\hline SIZE & 15.4005 & 13.4686 & 1.9319 & 15.4005 & 15.2340 & 0.1665 \\
\hline $\mathrm{BV}$ & 8601997 & 1473313 & 7128684 & 8601997 & 4955193 & 3646804 \\
\hline ADR & 0.3000 & 0.0885 & 0.2115 & 0.3000 & 0.3000 & 0 \\
\hline MV & 22364606 & 2862595 & 19502010 & 22364606 & 13558422 & 8806183 \\
\hline LEV & 2.1210 & 2.3453 & -0.2243 & 2.1210 & 2.0920 & 0.0290 \\
\hline MOB & 4.472 & 2.9537 & 1.5188 & 4.472 & 8.9755 & -4.5030 \\
\hline \multicolumn{7}{|c|}{2007} \\
\hline SIZE & 15.2376 & 13.5764 & 1.6612 & 15.2376 & 15.1816 & 0.0561 \\
\hline $\mathrm{BV}$ & 8260092 & 1414495 & 6845595 & 8260092 & 5029792 & 3230300 \\
\hline ADR & 0.2700 & 0.0712 & 0.2016 & 0.2700 & 0.2700 & 0 \\
\hline MV & 29556020 & 3574776 & 25981243 & 29556020 & 19965870 & 9590148 \\
\hline LEV & 2.1682 & 2.7426 & -0.5745 & 2.1682 & 2.1327 & 0.0355 \\
\hline MOB & 4.3600 & 3.2795 & 1.0805 & 4.3600 & 4.3082 & 0.0518 \\
\hline \multicolumn{7}{|c|}{2009} \\
\hline SIZE & 15.5961 & 13.7198 & 1.8763 & 15.5961 & 15.5591 & 0.0370 \\
\hline $\mathrm{BV}$ & 12268700 & 1901045 & 10367653 & 12268700 & 7697055 & 4571643 \\
\hline $\mathrm{ADR}$ & 0.2632 & 0.0669 & 0.1962 & 0.2632 & 0.2105 & 0.0526 \\
\hline MV & 26847570 & 3941301 & 22906271 & 26847570 & 19163590 & 7683981 \\
\hline LEV & 1.7726 & 3.6875 & -1.9148 & 1.7726 & 1.6732 & 0.0995 \\
\hline MOB & 4.5689 & -0.8678 & 5.4368 & 4.5689 & 4.2853 & 0.2837 \\
\hline
\end{tabular}

Note. The software used for this phase was the Core Team (2016), through the functions of the library matchit, found in the work of Ho et al. (2011).

These results suggest that the use of all firms becomes poor if the intention is to construct a counterfactual that approximates the condition of the firms treated before the adoption. Additionally, that the scores of the treatment and control groups are very close.

\subsection{Results of the Relevance of Accounting Information}

The results of the relevance of accounting information are interpreted by the analysis of the parameters of Equations 7 to 9, presented in Table 4. First, they corroborate with the theory that accounting information is relevant in the determination of market variables, through the results of the parameters $\beta_{2}$. In addition, they evidence the significant and positive association between the accounting profit and the market variables for all the proposed specifications. The finding that the adoption of IFRS increased this associative capacity between accounting profit and market variables was verified by significant positive result of $\delta_{2}$, validating hypothesis 1 of this study. This finding is in accordance with results obtained by Lima (2010) and Santos and Cavalcante (2014).

Differences between the market results of adopter and non-adopter firms were analyzed by the results of the parameters $\delta_{1}$. However, the results show that these parameters were statistically significant and positive in equation 8 and not significant for the specification of equation 9 . 
Table 4. Results of the models of relevance of accounting information

\begin{tabular}{|c|c|c|c|c|c|c|c|c|c|c|}
\hline \multirow{2}{*}{ Model } & \multicolumn{2}{|c|}{ Fixed effect } & \multicolumn{2}{|c|}{ Fixed effect } & \multicolumn{2}{|c|}{ Fixed effect } & \multicolumn{2}{|c|}{ OLS\# } & \multicolumn{2}{|c|}{ OLS\# } \\
\hline & coef. & t. & coef. & $\mathrm{t}$. & coef. & $\mathrm{t}$. & coef. & t. & coef. & t. \\
\hline Const. & $0.868 * * *$ & 40.0 & $0.863^{* * *}$ & 32.3 & $0.865^{* * * *}$ & 32.9 & $1.065^{* * * *}$ & 43.9 & $1.061 * * *$ & 43.5 \\
\hline IFRS & - & - & $0.052 *$ & 1.8 & -0.007 & -0.2 & -0.009 & -0.3 & - & - \\
\hline$\frac{\underline{\text { EARN }}}{\text { Pt-1 }}$ & $1.071^{* * *}$ & 5.3 & $1.059^{* *}$ & 2.2 & $0.894 *$ & 1.9 & $0.596^{* *}$ & 3.4 & $0.744 * * *$ & 4.4 \\
\hline$\frac{\text { BVE }}{\text { Pt-1 }}$ & $0.226 * * *$ & 7.3 & $0.224 * * *$ & 4.9 & $0.229 * * *$ & 4.9 & 0.015 & 0.8 & 0.011 & 0.6 \\
\hline $\begin{array}{c}\text { IFRS } \times \\
\text { EARN/ Pt-1 }\end{array}$ & - & - & - & - & $1.742 * * *$ & 2.7 & $1.712 * * *$ & 2.9 & - & - \\
\hline 2007 & - & - & - & - & - & - & -0.031 & -1.1 & -0.027 & -0.9 \\
\hline 2008 & - & - & - & - & - & - & $-0.197 * * *$ & -7.4 & $-0.191 * * *$ & -7.1 \\
\hline 2009 & - & - & - & - & - & - & $0.081 * * *$ & 3.0 & $0.090 * * *$ & 3.3 \\
\hline 2010 & - & - & - & - & - & - & $-0.083 * * *$ & -2.9 & $-0.066^{* *}$ & -2.4 \\
\hline $\mathrm{R}^{2}$ - adjusted & \multicolumn{2}{|c|}{0.0889} & \multicolumn{2}{|c|}{0.0917} & \multicolumn{2}{|c|}{0.0993} & \multicolumn{2}{|c|}{0.2436} & \multicolumn{2}{|c|}{0.2326} \\
\hline F test & \multicolumn{2}{|c|}{$\mathrm{F}=1.60 * * *$} & \multicolumn{2}{|c|}{$\mathrm{F}=1.59 * * *$} & \multicolumn{2}{|c|}{$\mathrm{F}=1.61 * * *$} & \multicolumn{2}{|c|}{$\mathrm{F}=1.14$} & \multicolumn{2}{|c|}{$\mathrm{F}=1.06$} \\
\hline Breusch-Pagan & \multicolumn{2}{|c|}{$\mathrm{LM}=1.9$} & \multicolumn{2}{|c|}{$\mathrm{LM}=1.8$} & \multicolumn{2}{|c|}{$\mathrm{LM}=1.6$} & \multicolumn{2}{|c|}{$\mathrm{LM}=4.2^{* *}$} & \multicolumn{2}{|c|}{$\mathrm{LM}=5.4 * *$} \\
\hline Hausman & \multicolumn{2}{|c|}{$\mathrm{H}=66.24 * * *$} & \multicolumn{2}{|c|}{$\mathrm{H}=65.97 * * *$} & \multicolumn{2}{|c|}{$\mathrm{H}=67.63^{* * *}$} & \multicolumn{2}{|c|}{$\mathrm{H}=44.64 * * *$} & \multicolumn{2}{|c|}{$\mathrm{H}=39.79 * * *$} \\
\hline
\end{tabular}

Note. A total of 730 firm-quarter observations were used. Coef. is the abbreviation for coefficient and t. is the statistic. The estimation of fixed effect models was performed using robust standard errors.

\#A Choice for those grouped least squares models also considered the criteria of Akaike and Hannan-Quinn.

The symbols $*, * *$ and $* * *$ represent significance at the $10 \%, 5 \%$ and $1 \%$ levels, respectively.

Regarding the analysis of the variable dummies for each year of the period investigated, it was found that all the estimated parameters were significant, except for the year 2007. The comparative results for 2006, including other variables, showed reduced values of returns in 2008 and 2010 and increased values in 2009, possibly because of effects of the international financial crisis that occurred in the interval. The behavior of these variables varies even within the voluntary adoption period, suggesting that their use to assert any impact of the rules is not appropriate. These results are in the assumptions proposed in this paper on the non-effectiveness of analysis of the standard using only temporal dummy variables for it, as factors other than the standard may interfere over time in the quality of accounting information.

When comparing the adjusted $\mathrm{R}^{2}$ of the models without the identification of IFRS with specifications that include the indicators of adoption of the standard, there is an improvement in the adjustments of the models that include the IFRS. The adjusted $\mathrm{R}^{2}$ values increase from 0.089 in the estimates of equation 7 to 0.092 and 0.100 in the estimates of equations 8 and 9 , respectively. For estimates that include time dummies, this value increases from 0.233 to 0.244 . In addition, these results were superior to those found in the similar specifications of Santos and Cavalcante (2014) and Santos et al. (2011).

In addition to the estimated equations, specifications with the value of the log-returns as dependent variable were estimated by following Kothari and Zimmerman (1995). This was to see whether significant changes in the results occur, which could be caused by scale effect, as explained by Easton and Sommers (2003). However, the results were very close to those found in the models of returns and so were not presented.

\subsection{Results of the Timeliness and Conservatism}

The results of conservative measures and timeliness are interpreted by analyzing the parameters estimated from equations 10 to 15 listed in Tables 5 and 6.

When checking the estimation results, it was found that for all regressions of all proposed equations, the coefficient $\alpha_{1}$ was significant and positive, confirming the theory that the returns are informative for determining the accounting profit and thus considered timely. These results differ from those presented in Santos and Cavalcante (2014) and Santos et al. (2011), in which none of the proposed specifications for this coefficient were significant at the $5 \%$ level. However, the results of the coefficients $\dot{\delta}_{1}$, which identify whether the adoption of IFRS increases the companies' earnings, were not significant in any of the regressions. The coefficient $\dot{\delta}_{2}$, which evaluates the informational timeliness arising from the adoption of IFRS, is also not significant. These results corroborate those found in Santos and Cavalcante (2014), which do not show that IFRS have made accounting profit more timely. Thus, hypothesis 2 of this study, which states that the adoption of IFRS in Brazil 
increases the informational timeliness of accounting profit, is not confirmed.

Table 5. Results of the timeliness model

\begin{tabular}{|c|c|c|c|c|c|c|}
\hline \multirow{2}{*}{ Model } & \multicolumn{2}{|c|}{ Random effect } & \multicolumn{2}{|c|}{ Random effect } & \multicolumn{2}{|c|}{ Random effect } \\
\hline & coef. & t. & coef. & t. & coef. & t. \\
\hline Const. & $0.0292 * * *$ & 8.5 & $0.0287 * * *$ & 8.2 & $0.0288 * * *$ & 8.1 \\
\hline $\mathrm{R}$ & $0.0460^{* * *}$ & 6.6 & $0.0456^{* * *}$ & 6.5 & $0.0432 * * *$ & 5.8 \\
\hline IFRS & - & - & 0.0032 & 0.6 & 0.0018 & 0.3 \\
\hline RxIFRS & - & - & - & - & 0.0197 & 0.9 \\
\hline $\mathrm{R}^{2}$-adjusted & \multicolumn{2}{|c|}{0.0577} & \multicolumn{2}{|c|}{0.05816} & \multicolumn{2}{|c|}{0.0592} \\
\hline F Test & \multicolumn{2}{|c|}{$\mathrm{F}=4.68 * * *$} & \multicolumn{2}{|c|}{$\mathrm{F}=4.691 * * *$} & \multicolumn{2}{|c|}{$\mathrm{F}=4.699 * * *$} \\
\hline Breusch-Pagan & \multicolumn{2}{|c|}{$\mathrm{LM}=181.9^{* * *}$} & \multicolumn{2}{|c|}{$\mathrm{LM}=182.3^{* * *}$} & \multicolumn{2}{|c|}{$\mathrm{LM}=183.3 * * *$} \\
\hline Hausman & \multicolumn{2}{|c|}{$\mathrm{H}=0.018$} & \multicolumn{2}{|c|}{$\mathrm{H}=0.275$} & \multicolumn{2}{|c|}{$\mathrm{H}=0.641$} \\
\hline
\end{tabular}

Note. A total of 730 firm-quarter observations were used. Coef. is the abbreviation for coefficient and t. is the statistic.

The symbols $*, * *$ and $* * *$ represent significance at the $10 \%, 5 \%$ and $1 \%$ levels, respectively.

Regarding the conditional conservatism of the accounting profit for the firms adopting standards and their pairs, the results of the coefficients $\alpha_{2}$ and $\alpha_{3}$ did not present significance or their signs were contrary to expectations, not confirming the asymmetric recognition of economic loss in relation to the gain. The coefficient $\ddot{\delta}_{2}$, which checks the change of conservatism arising from the change from the domestic norm to IFRS, also showed no statistically significant results for any of the proposed specifications. This indicates that international standards do not impact on the conservatism of the accounting profit in Brazil for the period investigated, therefore not confirming hypothesis 3 of this study. These results are similar to those found in Santos et al. (2011) and Santos and Cavalcante (2014).

Table 6. Conservatism model results

\begin{tabular}{|c|c|c|c|c|c|c|c|c|c|c|}
\hline \multirow{2}{*}{ Model } & \multicolumn{2}{|c|}{ Fixed effect } & \multicolumn{2}{|c|}{ Fixed effect } & \multicolumn{2}{|c|}{ Random effect } & \multicolumn{2}{|c|}{ Random effect } & \multicolumn{2}{|c|}{ Random effect } \\
\hline & coef. & t. & coef. & $\mathrm{t}$. & coef. & t. & coef. & $\mathrm{t}$. & coef. & t. \\
\hline Const. & $0.025 * * *$ & 7.7 & $0.024 * * *$ & 6.6 & $0.026 * * *$ & 6.0 & $0.033 * * *$ & 5.3 & $0.031 * * *$ & 5.8 \\
\hline NEG & 0.003 & 0.8 & 0.004 & 0.8 & 0.002 & 0.4 & 0.002 & 0.5 & 0.004 & 0.5 \\
\hline $\mathrm{R}$ & $0.068^{* * *}$ & 2.6 & $0.067 * * *$ & 2.6 & $0.060 * * *$ & 3.9 & $0.059 * * *$ & 3.7 & $0.066 * * *$ & 4.1 \\
\hline $\begin{array}{c}\text { NEGx } \\
\text { R }\end{array}$ & $-0.031 *$ & -1.7 & $-0.031 * * *$ & -1.7 & -0.021 & -0.9 & -0.029 & -1.3 & $-0.039 *$ & -1.7 \\
\hline IFRS & - & - & 0.004 & 0.7 & 0.003 & 0.5 & - & - & 0.004 & 0.5 \\
\hline \multicolumn{11}{|l|}{ NEGxR } \\
\hline $\mathrm{x}$ & - & - & - & - & -0.002 & -0.0 & - & - & 0.006 & 0.1 \\
\hline \multicolumn{11}{|l|}{ IFRS } \\
\hline 2007 & - & - & - & - & - & - & -0.008 & -1.4 & -0.009 & -1.5 \\
\hline 2008 & - & - & - & - & - & - & $-0.012 * *$ & -2.0 & $-0.013^{* *}$ & -2.2 \\
\hline 2009 & - & - & - & - & - & - & -0.005 & -0.9 & -0.006 & -1.1 \\
\hline 2010 & - & - & - & - & - & - & -0.005 & -0.8 & -0.006 & -1.0 \\
\hline $\mathrm{R}^{2}$-adjusted & \multicolumn{2}{|c|}{0.2304} & \multicolumn{2}{|c|}{0.2298} & \multicolumn{2}{|c|}{0.059} & \multicolumn{2}{|c|}{0.0648} & \multicolumn{2}{|c|}{0.0649} \\
\hline Teste F & \multicolumn{2}{|c|}{$\mathrm{F}=4.73 * * *$} & \multicolumn{2}{|c|}{$\mathrm{F}=4.74 * * *$} & \multicolumn{2}{|c|}{$\mathrm{F}=4.68 * * *$} & \multicolumn{2}{|c|}{$\mathrm{F}=4.77 * * *$} & \multicolumn{2}{|c|}{$\mathrm{F}=4.76^{*}$} \\
\hline Breusch-Pagan & \multicolumn{2}{|c|}{$\mathrm{LM}=176.9 * * *$} & \multirow{2}{*}{\multicolumn{2}{|c|}{$\begin{aligned} \mathrm{LM} & =177.2^{* * *} \\
\mathrm{H} & =9.686^{* *}\end{aligned}$}} & \multirow{2}{*}{\multicolumn{2}{|c|}{$\begin{array}{c}\mathrm{LM}=179.2 * * * \\
\mathrm{H}=5.269\end{array}$}} & \multirow{2}{*}{\multicolumn{2}{|c|}{$\begin{aligned} \mathrm{LM} & =181.7 * * * \\
\mathrm{H} & =10.764\end{aligned}$}} & \multirow{2}{*}{\multicolumn{2}{|c|}{$\begin{aligned} \mathrm{LM} & =181.0^{* * *} \\
\mathrm{H} & =12.031\end{aligned}$}} \\
\hline Hausman & $\mathrm{H}=9$ & $2 * *$ & & & & & & & & \\
\hline
\end{tabular}

Note. A total of 730 firm-quarter observations were used. Coef. is the abbreviation for coefficient and t. is the statistic. The estimation of fixed effect models was performed using robust standard errors.

The symbols *,** and $* * *$ represent significance at the $10 \%, 5 \%$ and $1 \%$ levels, respectively.

Regarding the analysis of the dummy variable for each year in the proposed models, only the year 2008 showed a significant result, which, given its negative sign, may have been due to other factors such as the international financial crisis. As mentioned in the results of the models of the relevance of accounting information, only the use of these variables does not seem to be consistent to assert any impact of the norms in this case. 


\section{Concluding Remarks}

The doubt about the precise relationship between the accounting information quality of Brazilian firms and the adoption of international accounting standards was one of the motivating questions of this research, particularly the method and the manner in which the national literature addresses the isolation of the effect of the standard and performs the calculation of its measures of interest. In general, the evaluations are performed without a process of pretreating or the data randomization for the construction of any suitable counterfactual. Therefore, this article aimed to assess whether the adoption of international accounting standards is associated with a higher accounting information quality in Brazil, through an alternative approach.

To achieve this, an empirical strategy of two steps was adopted: the first involving the matching by propensity score and the construction of control groups, and the second, the estimation of measures of accounting information quality through panel data models. Thus, it sought to mitigate possible problems of selection bias, as well as unobserved variables that could interfere with measurements of interest.

The results of the balance of the matching were satisfactory, in terms of the construction of control groups that meet the propensity score matching model's assumptions and of the proximity of the scores of values and average results of the variables between the treatment groups and control groups.

Regarding the investigation of the hypothesis that the adoption of IFRS increased the relevance of accounting information, the results were favorable for all proposed specifications. Thus, for companies that have adopted international standards, accounting profit has become more relevant in the determination of market variables. However, the results did not verify the hypothesis that the adoption of IFRS increased the timeliness and level of conservatism of the accounting profit. That is, the measures of conservatism and timeliness do not exhibit significant variations in front of adoption of standards in Brazil. Hence, the adoption of the standards did not make the returns and asymmetric recognition of losses more informative. Another important aspect is the results of the temporal dummy variable; only their use does not seem to provide sufficient evidence to confirm or refute the impact of adopting IFRS for the sample investigated.

The study has some limitations. First, the period for analysis is short, and it would be interesting to extend the time horizon. Likewise, the sample of companies analyzed is small. Therefore, it is worth repeating the study using some unbalanced panel data method to increase the number of firms and the time horizon. Another point to be explored in the future would be to expand the number of covariates used in the Matching stage.

\section{References}

Abadie, A., \& Imbens, G. W. (2006). Large sample properties of matching estimators for average treatment effects. Econometrica, 74, 235-267. http://dx.doi.org/10.1111/j.1468-262.2006.00655.x

Ahmed, K., Chalmers, K., \& Khlif, H. (2013). A meta-analysis of IFRS adoption effects. International Journal of Accounting, 48, 173-217. http://dx.doi.org/10.1016/j.intacc.2013.04.002

Apergis, N. (2015). The role of IFRS in financial reporting quality: Evidence from a panel of MENA countries. International Journal of Economics and Finance, 7(10), 182. http://dx.doi.org/10.5539/ijef.v7n10p182

Armstrong, C. S., Barth, M. E., \& Riedl, E. J. (2010). Market reaction to the adoption of IFRS in Europe. The Accounting Review, 85(1), 31-61. http://dx.doi.org/10.2308/accr.2010.85.1.31

Barth, M, E., Landsman, W. R., \& Lang, M. H. (2008). International accounting standards and accounting quality. Journal of Accounting Research, 46, 467-498. http://dx.doi.org/10.1111/j.1475-679X.2008.00287.x

Barth, M. E., Beaver, W. H., \& Landsman, W. R. (2001). The relevance of the value-relevance literature for financial accounting standard setting: Another view. Journal of Accounting and Economics, 31, 77-104. http://dx.doi.org/10.1016/S0165-4101(01)00019-2

Barth, M., \& Clinch, G. (2009). Scale effects in capital markets-based accounting research. Journal of Business Finance \& Accounting, 36, 253-288. http://dx.doi.org/10.1111/j.1468-5957.2009.02133.x

Basu, S. (1997). The conservatism principle and the asymmetric timeliness of earnings. Journal of Accouting and Economics, 24, 3-37. http://dx.doi.org/10.1016/S0165-4101(97)00014-1

Beaver, W., Lambert, R., \& Morse, D. (1980). The information content of security prices. Journal of Accounting and Economics, 2(1), 3-28. http://dx.doi.org/10.1016/0165-4101(80)90013-0

Bilgic, F. A., \& Ibis, C. (2013). Effects of new financial reporting standards on value relevance - A study about Turkish stock markets. International Journal of Economics and Finance, 5(10), 126. http://dx.doi.org/10.5539/ijef.v5n10p126 
Callao, S., Jarne, J. I., \& Laínez, J. A. (2007). Adoption of IFRS in Spain: Effect on the comparability and relevance of financial reporting. Journal of International Accounting Auditing \& Taxation, 16(2), 148-178. http://dx.doi.org/10.1016/j.intaccaudtax.2007.06.002

Cameron, A. C., \& Trivedi, P. K. (2005). Microeconometrics: Methods and applications. Cambridge: Cambridge university press. http://dx.doi.org/10.1017/CBO9780511811241

Dowa, A., Elgammi, A. M., Elhatab, A., \& Mutat, H. A. (2017). Main worldwide cultural obstacles on adopting international financial reporting standards (IFRS). International Journal of Economics and Finance, 9(2), 172. http://dx.doi.org/10.5539/ijef.v9n2p172

Easton, P. D., \& Sommers, G. A. (2003). Scale and the scale effect in market-based accounting research. Journal of Business Finance \& Accounting, 30(12), 25-56. http://dx.doi.org/10.1111/1468-5957.00482

Francis, J., \& Schipper, K. (1999) Have financial statements lost their relevance? Journal of Accounting Research, 37, 319-352. http://dx.doi.org/10.2307/2491412

Francis, J., Lafond, R., Olsson, P. M., \& Schipper, K. (2004). Costs of equity and earnings attributes. The accounting review, 79(4), 967-1010. http://dx.doi.org/10.2308/accr.2004.79.4.967

Garrouch, H. (2016). Reaction of foreign institutional investors to nandatory IFRS adoption: French evidence. International Journal of Economics and Finance, 8(11), 30. http://dx.doi.org/10.5539/ijef.v8n11p30

Gil-Alana, L. A., Iniguez-Sanchez, R., \& Lopez-Espinosa, G. (2011). Endogenous problems in crosssectional valuation models based on accounting information. Review of Quantitative Finance and Accounting, 37(2), 245-265. http://dx.doi.org/10.1007/s11156-010-0203-2

Gonçalves, J. C, Batista, B. L. L, Macedo, M. A. S, \& Marques, A. V. C. (2014). Análise do impacto do processo de convergência às normas internacionais de contabilidade no Brasil: Um estudo com base na relevância da informação contábil. Revista Universo Contábil, 10(3), 25-43. http://dx.doi.org/10.4270/RUC.2014318

Hail, L., Leuz, C., \& Wysocki, P. (2010). Global accounting convergence and the potential adoption of IFRS by the U.S. (part II). Accounting Horizons, 24, 567-588. http://dx.doi.org/10.2308/acch.2010.24.4.567

Ho, D., Imai, K., King, G., \& Stuart, E. (2007). Matching as nonparametric preprocessing for reducing model dependence in parametric causal inference. Political Analysis, 15, 199-236. http://dx.doi.org/10.1093/pan/mp1013

Ho, D., Imai, K., King, G., \& Stuart, E. (2011). Matchit: Nonparametric preprocessing for parametric causal inference. Journal of Statistical Software, 42, 1-28. http://dx.doi.org/10.18637/jss.v042.i08

Houqe, M. N., Van Zijl, T., Dunstan, K., \& Karim, A. W. (2012). The effect of IFRS adoption and investor protection on earnings quality around the world. The International journal of accounting, 47(3), 333-355. http://dx.doi.org/10.1016/j.intacc.2012.07.003

Iatridis, G. (2010). International financial reporting standards and the quality of financial statement information. International Review of Financial Analysis, 19, 193-204. http://dx.doi.org/10.1016/j.irfa.2010.02.004

Imbens, G. W. (2015). Matching methods in practice: Three examples. Journal of Human Resources, 50(2), 373-419. http://dx.doi.org/10.3368/jhr.50.2.373

Karampinis, N., \& Hevas, D. (2009). The effect of the mandatory application of IFRS on the value relevance do accounting data: Some evidence from Greece. European Research Studies, 12(1), 73-100.

Kargin, S. (2013). The impact of IFRS on the value relevance of accounting information: evidence from Turkish firms. International Journal of Economics and Finance, 5(4), 71-80. http://dx.doi.org/10.5539/ijef.v5n4p71

Khandker, S. R., Koolwal, G. B., \& Samad, H. A. (2010). Handbook on Impact Evaluation: Quantitative Methods and Practices. Washington: World Bank Publications. http://dx.doi.org/10.1596/978-0-8213-8028-4

Klimczak, K. M. (2011). Market reaction to mandatory IFRS adoption: evidence from Poland. Accounting and Management Information Systems, 10(2), 228-248.

Kothari, S. P., \& Zimmerman, J. L. (1995). Price and return models. Journal of Accounting and Economics, 20(2), 155-192. http://dx.doi.org/10.1016/0165-4101(95)00399-4

Lima, J. B. N. (2010). A relevância da informação contábil e o processo de Convergência para as Normas IFRS no Brasil (Doctoral thesis, University of São Paulo, São Paulo, Brazil). Retrieved from http://www.teses.usp.br/teses/disponiveis/12/12136/tde-24032011-185955/pt-br.php 
Ohlson, J. A. (1995). Earnings, book values, and dividends in equity valuation. Contemporary Accounting Research, 11(2), 661-687. http://dx.doi.org/10.1111/j.1911-3846.1995.tb00461.x

Olfa, B. J., \& Hamadi, M. (2015). The impact of the IAS/IFRS adoption on the predictive quality of discretionary accruals: A comparison between the French and the British context. International Journal of Economics and Finance, 7(6), 208. http://dx.doi.org/10.5539/ijef.v7n6p208

Paul, A., Walton, P. J., \& Yang, D. (2012). Voluntary adoption of IFRS: A study of determinants for UK unlisted firms. SSRN Electronic Journal, 1-42. http://dx.doi.org/10.2139/ssrn.1978986

Peixoto, B., Pinto, C. C. X., Lima, L., Foguel, M. N., \& Barros, R. P. (2012). Avaliação Econômica de Projetos Sociais (1st ed.). Organized by Naercio Menezes Filho. São Paulo: Dinâmica Gráfica e Editora.

R Core Team. (2016). R: A language and environment for statistical computing. R Foundation for Statistical Computing, Vienna, Austria. URL https://www.R-project.org/.

Rosenbaum, P. R., \& Rubin, D. B. (1983). The central role of the propensity score in observational studies for causal effects. Biometrika, 70(1), 41-55. http://dx.doi.org/10.1093/biomet/70.1.41

Santos, L. P. G., Lima, G. A. S. F., Freitas, S. C., \& Lima, I. S. (2011). Efeito da Lei 11.638/07 sobre o conservadorismo condicional das empresas listadas BM\&FBOVESPA. Revista Contabilidade \& Finanças, 22(56), 174-188. http://dx.doi.org/10.1590/S1519-70772011000200004

Santos, M. A. C., \& Cavalcante, M. E. M. A. D. C. (2014). O efeito da adoção dos IFRS sobre a relevância informacional do lucro contábil no Brasil. Revista Contabilidade \& Finanças, 25(66), 228-241. http://dx.doi.org/10.1590/1808-057x201410690

Soderstrom, N. S., \& Sun, K. J. (2007). IFRS adoption and accounting quality: A review. European Accounting Review, 16(4), 675-702. http://dx.doi.org/10.1080/09638180701706732

Tendeloo, B. V, \& Vanstraelen, A. (2005). Earnings management under German GAAP versus IFRS. European Accounting Review, 14(1), 155-180. http://dx.doi.org/10.1080/0963818042000338988

\section{Appendix A}

\section{Matching Results}
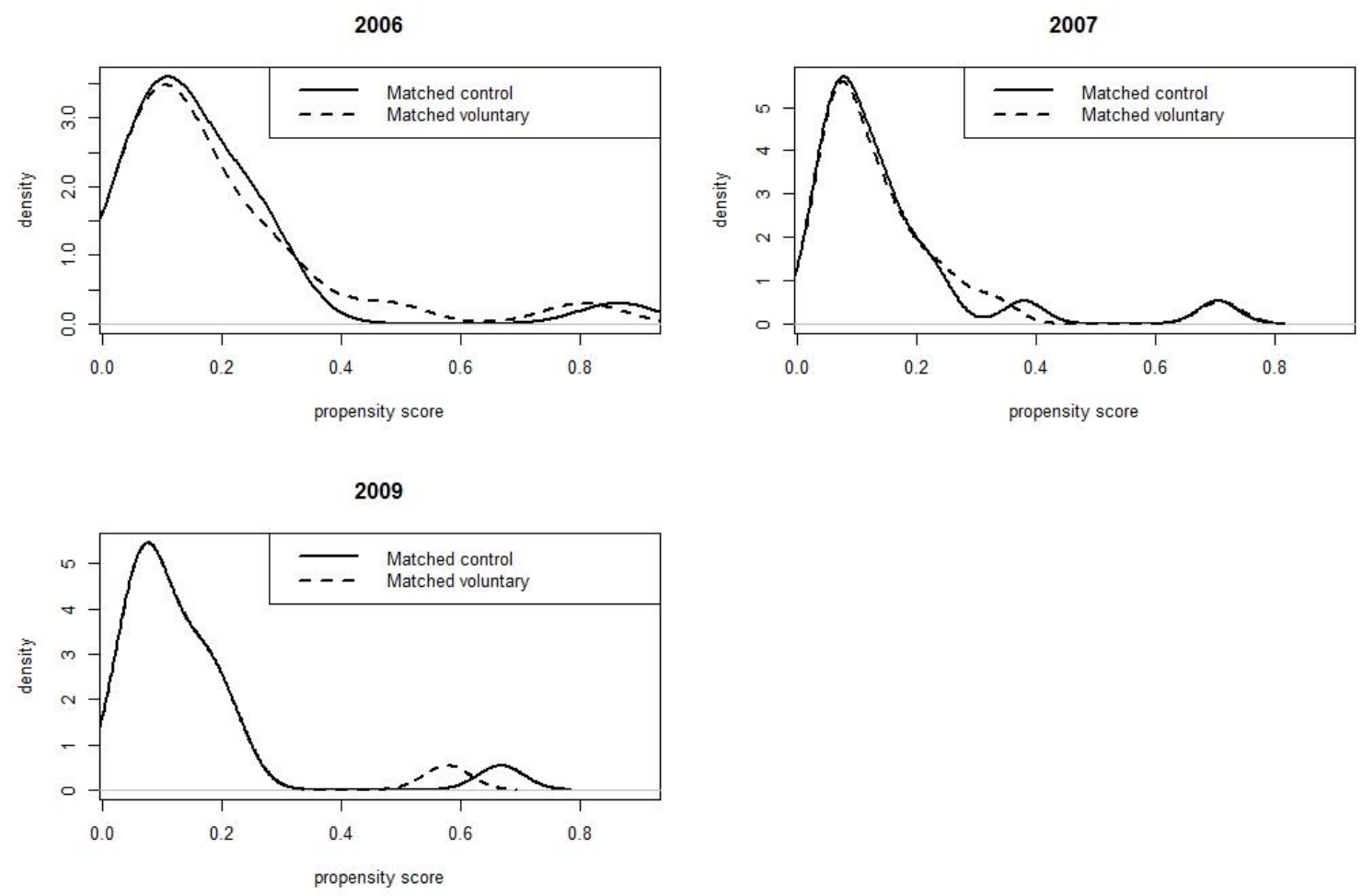

Figure A1. Density of propensity scores 


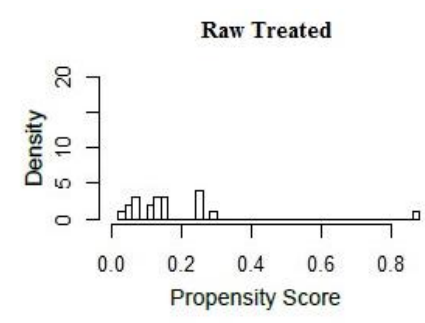

Raw Control

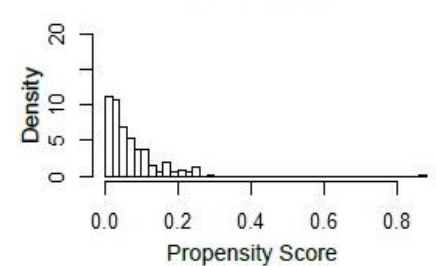

Matched Treated

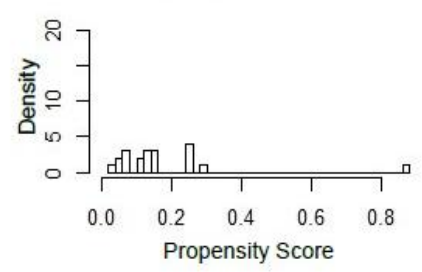

Matched Control

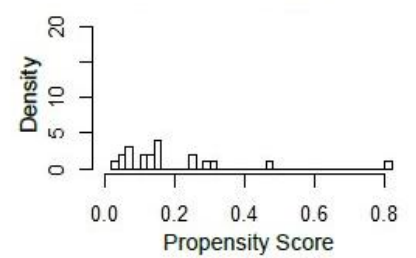

Figure A2. Histograms (2006)

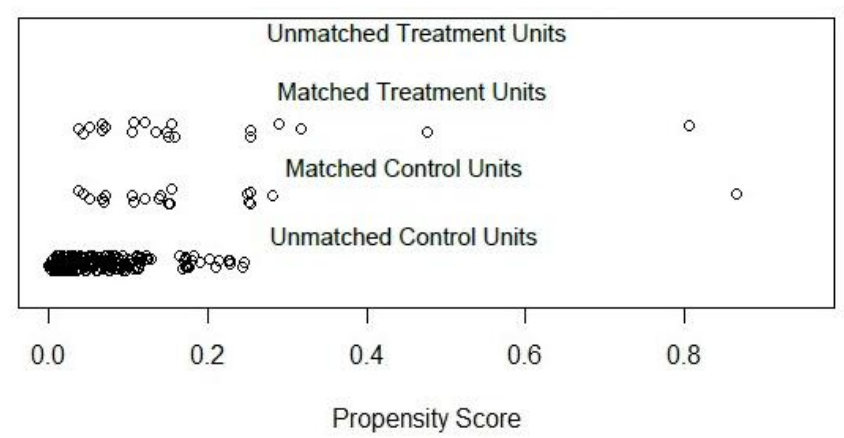

Figure A3. Scores of treatments and controls (2006)

Raw Treated

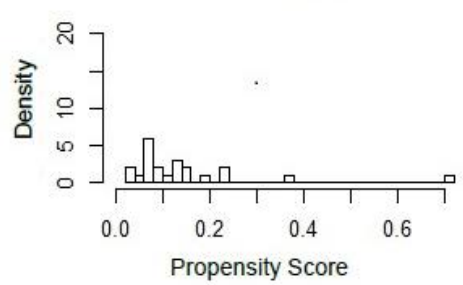

Raw Control

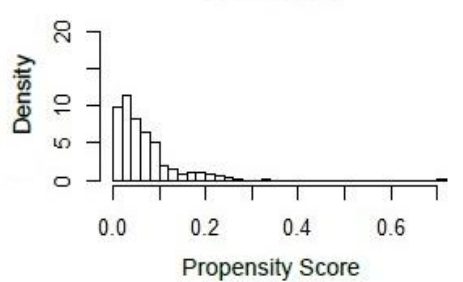

Matched Treated

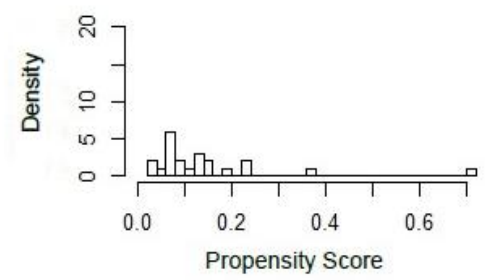

Matched Control

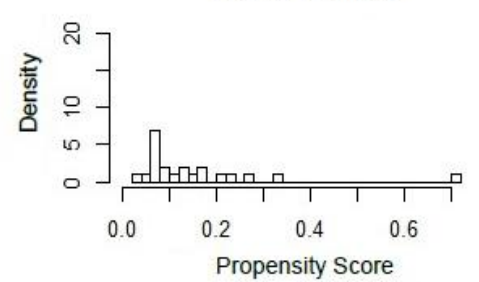

Figure A4. Histograms (2007) 


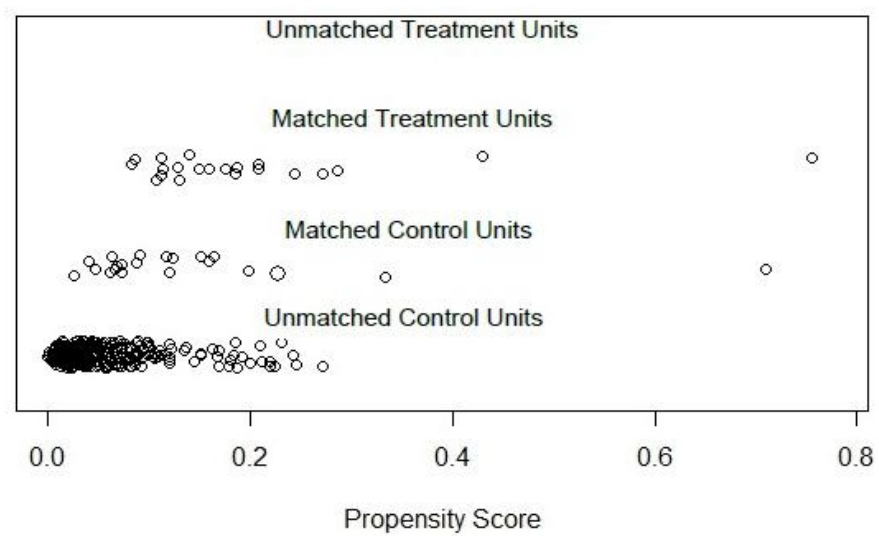

Figure A5. Scores of treatments and controls (2007)

Raw Treated

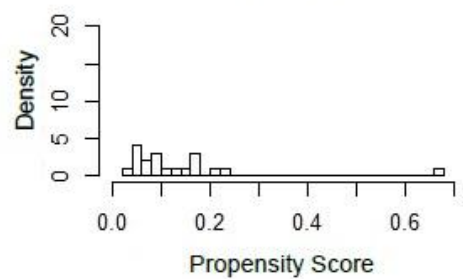

Raw Control

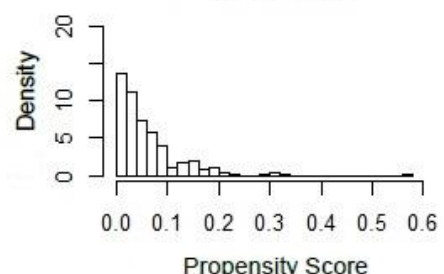

Matched Treated

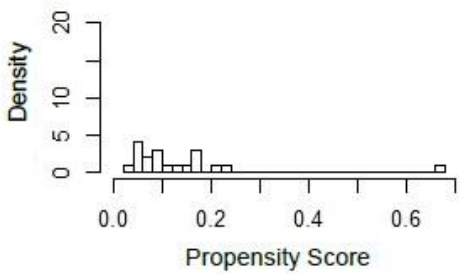

Matched Control

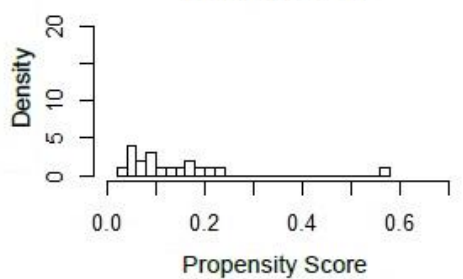

Figure A6. Histograms (2009)

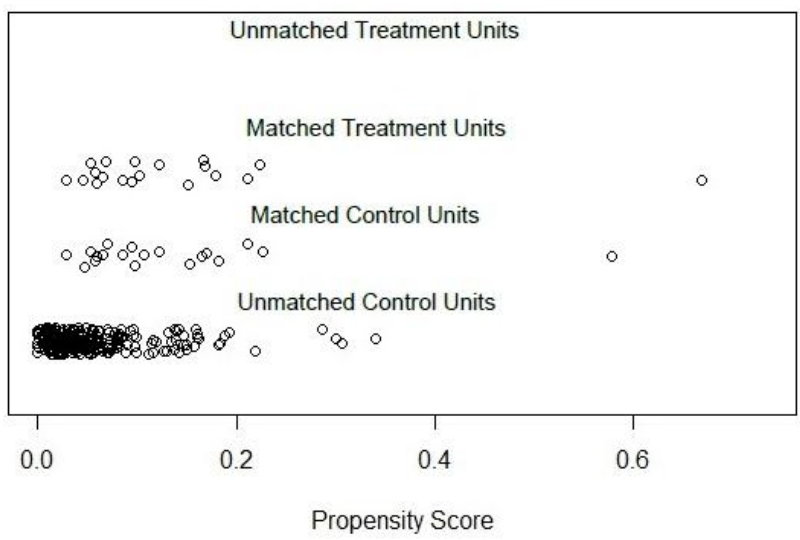

Figure A7. Scores of treatments and controls (2009)

\section{Copyrights}

Copyright for this article is retained by the author(s), with first publication rights granted to the journal.

This is an open-access article distributed under the terms and conditions of the Creative Commons Attribution license (http://creativecommons.org/licenses/by/4.0/). 